\title{
Improving Indonesian Learning Results In Suggestion Sentences With Guided Discovery Learning Model
}

\section{Barra Ariyanto Putro}

SD Negeri 2 Metuk

baraheafy@gmail.com

\section{Article History}

accepted $14 / 11 / 2020$

\begin{abstract}
The purpose of this research was to improve the learning outcomes of students in the Indonesian language lesson, Suggestion Sentence Material in grade III elementary schools with the guided discovery learning model. The research conducted was Classroom Action Research (PTK). The sequence of research activities includes 4 stages including: (1) planning, (2) implementation, (3) observation, and (4) reflection. The learning outcomes of students in the first cycle after carrying out the post test were $25 \%$. In the second cycle students who completed after carrying out the post test were $83 \%$. In the third cycle students who completed after carrying out the post test were 92\%. The results of this study indicate that: (1) the application of the guided discovery learning model is in accordance with the material, where the steps of the guided discovery learning model include: a) introduction, b) repetition, c) overview, d) investigation, e) representation, $f$ ) discussion, g) findings, $h$ ) application, i) conclusions, and j) assessment. (2) learning through the guided discovery learning model has increased in each cycle.
\end{abstract}

Keywords: Learning outcomes, Guided discovery learning, Indonesian language

\section{Abstrak}

Tujuan dari penelitian ini adalah untuk meningkatkan hasil belajar peserta didik pada mupel Bahasa Indonesia, Materi Kalimat Saran di sekolah dasar kelas III dengam model pembelajaran guided discovery learning. Penelitian yang dilakukan adalah Penelitian Tindakan Kelas (PTK). Urutan kegiatan penelitian mencakup 4 tahap meliputi: (1) perencanaan, (2) pelaksanaan, (3) pengamatan, dan (4) refleksi. Hasil belajar peserta didik pada siklus I setelah melaksanakan post test sebesar $25 \%$. Pada siklus II peserta didik yang tuntas setelah melaksanakan post test sebesar $83 \%$. Pada siklus III peserta didik yang tuntas setelah melaksanakan post test sebesar 92\%. Hasil penelitian ini menunjukkan bahwa: (1) penerapan model guided discovery learning telah sesuai dengan materi, dimana langkah-langkah model guided discovery learning meliputi: a) pendahuluan, b) pengulangan, c) gambaran, d) penyelidikan, e) representasi, f) diskusi, g) penemuan, h) aplikasi, i) kesimpulan, dan j) penilaian. (2) pembelajaran melalui model guided discovery learning mengalami peningkatan pada setiap siklusnya.

Kata kunci: Hasil belajar, Guided discovery learning, Bahasa Indonesia

Social, Humanities, and Education Studies (SHEs): Conference Series https://jurnal.uns.ac.id/shes 


\section{PENDAHULUAN}

Salah satu masalah urgen yang dihadapi dunia pendidikan kita saat ini adalah lemahnya proses pembelajaran. Dalam proses pembelajaran siswa kurang didorong untuk mengembangkan kemampuan berfikir. Proses pembelajaran dikelas diarahkan kepada kemampuan anak untuk menghafal informasi. Otak anak dipaksa untuk mengingat dan menimbun berbagai informasi tanpa dituntut untuk memahami informasi yang diingatnya itu. Proses pembelajaran yang berjalan saat ini secara umum masih menempatkan anak sebagai obyek dan menempatkan guru pusat kegiatan pembelajaran. Peserta didik tidak mendapatkan kesempatan untuk dapat berpartisipasi secara aktif untuk mengkonstruksi pengetahuan yang didapatnya.

Pada tanggal 24 Maret 2020 Menteri Pendidikan dan Kebudayaan Republik Indonesia mengeluarkan Surat Edaran Nomor 4 Tahun 2020 tentang Pelaksanaan Kebijakan Pendidikan dalam Masa Darurat Penyebaran COVID, dalam Surat Edaran tersebut dijelaskan bahwa proses belajar dilaksanakan di rumah melalui pembelajaran daring/jarak jauh dilaksanakan untuk memberikan pengalaman belajar yang bermakna bagi siswa.

Hal ini menjadi tantangan bagi guru untuk tetap dapat menciptakan pembelajaran yang menyenangkan, menarik dan aktif. Walaupun pembelajaran dilaksanakan jarak jauh atau daring, guru harus mampu meningkatkan keaktifan siswa. Keaktifan siswa dapat tercipta melalui penerapan media pembelajaran yang menarik. Salah satu media pembelajaran yang menarik dalam pembelajaran daring adalah memanfaatkan Google Meet. Sejak menyebarnya pandemi COVID-19 di seluruh dunia telah memaksa banyak pekerja untuk tetap bekerja dari rumah dan mengadakan pertemuan atau meeting secara online saja. Ini membuat banyak aplikasi online meeting atau web conferencing seperti Zoom, Skype dan kini Google Meet menjadi pilihan banyak orang untuk tetap terhubung.

Berdasarkan hasil observasi di SD Negeri 2 Metuk menunjukkan bahwa banyak peserta didik dan orang tua kurang antusias dengan pembelajaran daring karena kemampuan device yang belum memadahi. Hal ini dapat dilihat dalam pembelajaran Tema 4 Subtema 1 Pembelajaran ke 4, dari 12 peserta didik di kelas III, hanya 50\% saja yang dapat mengikuti pembelajaran dan mengumpulkan tugas. Banyak masalahmasalah yang timbul diantaranya guru dan siswa belum siap dengan proses belajar daring yang harus mengahadirkan sarana dan prasarana yang mendukung. Siswa kurang aktif belajar secara mandiri dan guru tidak memaksimalkan penggunaan media dan model pembelajaran yang sesuai. Hal ini menyebabkan rendahnya hasil belajar siswa dan tidak tercapainya tujuan pembelajaran.

Pada kurikulum 2013, disarankan untuk menggunakan model pembelajaran yang dapat menuntun siswa untuk aktif dalam pembelajaran. Model-model pembelajaran tersebut antara lain: project based learning, problem based learning, dan discovery learning (pembelajaran penemuan). Ada dua jenis pembelajaran penemuan yaitu pembelajaran penemuan murni (free discovery) dan pembelajaran penemuan terbimbing (guided discovery).

Untuk mendapatkan hasil belajar yang maksimal, guided discovery learning sangat diperlukan oleh siswa. Menurut Eggen model guided discovery learning (temuan terbimbing) adalah satu pendekatan mengajar dimana guru memberi siswa contoh-contoh topik spesifik dan memandu siswa untuk memahami topik tersebut. Menurut Carin \& Sund (1989:95) penemuan terbimbing dapat membantu peserta didik menjadi pribadi yang mandiri serta bertanggung jawab terhadap pembelajaran yang mereka lakukan sendiri. Peserta didik menjadi lebih memotivasi diri saat belajar dengan menemukan sesuatu sendiri, daripada hanya dengan mendengar saja. Mereka belajar untuk melakukan kegiatan mereka dengan memanipulasi lingkungan mereka secara lebih aktif hingga meraih kepuasan dari mengatasi permasalahan. Pada guided discovery learning guru bertindak sebagai fasilitator dan memberikan peserta didik 
lingkungan yang responsive terhadap kebutuhan mereka. Guru memberikan peserta didik kesempatan untuk mencoba berbagai hal tanpa takut akan hukuman.

Menurut Westwood (2008:29) ada beberapa karakteristik pembelajaran discovery learning yaitu pada pelaksanaan pembelajaran peserta didik dihadapkan pada sebuah topik permasalahan yang dilontarkan oleh guru, guru dan peserta didik bekerjasama mencari cara agar dapat melakukan penyelidikan topik dimana guru memberi arahan tentang hal yang harus dilakukan dan bagaimana cara menyelesaikan masalah yang diberikan, peserta didik mengumpukan data hasil diskusi baik secara individu atau secara kelompok tentang apa yang sudah ditemukan pada permasalahan tersebut, kemudian peserta didik membuat kesimpulan dari hasil pemecahan masalah, guru membantu untuk meluruskan pemahaman peserta didik dan membenarkan jika ada pendapat yang keliru. Capel, Leask, \& Turner (2009:254) berpendapat bahwa karakteristik model discovery learning adalah (1) exploring and solving problems to create, combine and generalize knowledge; (2) centered on the learner, (3) activities to combine new knowledge and existing knowledge. Ini berarti peserta didik mengeksplorasi serta memecahkan masalah, peserta didik menjadi pusat dalam pelaksanaan pembelajaran berkaitan dengan proses aktivitas bagaimana peserta didik menemukan pembelajaran yang baru kemudian menggabungkannya dengan pengalaman yang sudah ada. Hal ini selaras dengan pendapat Hosnan (2014: 284) bahwa ciri utama belajar menemukan, yaitu (1) mengeksplorasi dan memecahkan masalah untuk menciptakan, menggabungkan, dan menggeneralisasi pengetahuan; (2) berpusat pada siswa; (3) kegiatan untuk menggabungkan pengetahuan baru dan pengetahuan yang sudah ada. kegiatan penemuan terbimbing dapat memiliki tiga elemen: eksplorasi, penemuan, dan penemuan (Carin \& Sund, 1989: 104).

Sementara itu, Syah (2014:243) berpendapat bahwa metode guided discovery learning dapat dilakukan dengan dimulai dari fase stimulus, dimana peserta didik diberi rangsangan untuk berpikir melalui masalah yang disediakan oleh guru. Pada fase statement problem, peserta didik melakukan kegiatan identifikasi masalah. Selanjutnya, fase data collection dimana pada fase ini peserta didik mencari informasi terkait masalah yang relevan. Fase data processing, peserta didik mengolah informasi yang telah diperoleh untuk menghasilkan suatu dugaan jawaban yang tepat untuk masalah yang diberikan. Pada fase verification, dilakukan proses verifikasi oleh peserta didik dengan guru melakukan arahan agar tidak bias. Dan pada fase generalization, peserta didik menarik sebuah kesimpulan yang dapat dijadikan prinsip umum dan berlaku untuk semua kejadian atau masalah yang sama.

Agar pelaksanaan model guided discovery learning ini berjalan dengan efektif, beberapa langkah yang perlu ditempuh oleh guru menurut (Markaban, 2006:16) adalah sebagai berikut: (1) Siswa diberikan suatu permasalahan, (2) Siswa menyusun, memproses, mengorganisir, dan menganalisis data tersebut dengan bimbingan guru, (3) Guru menyusun penyelesaian, dan (4) Membuat kesimpulan dari hasil yang telah diperoleh Berdasarkan beberapa pendapat para ahli di atas. Langkah-langkah model guided discovery learning yang digunakan dalam penelitian ini adalah stimulus, problem statement (identifikasi masalah), data collection (pengumpulan data), data processing (pengolahan data), verification, dan generalization (penarikan kesimpulan/generalisasi).

\section{METODE}

Penelitian ini merupakan penelitian tindakan kelas (classroom action research). Pendekatan tindakan difokuskan pada penerapan model guided discovery learning dalam pembelajaran mupel Bahasa Indonesia materi Kalimat Saran pada peserta didik kelas 3 SD Negeri 2 Metuk. Rancangan penelitian yang digunakan adalah model siklus 
yaitu tindakan pembelajarannya dilakukan secara berdaur-daur dan berkelanjutan (siklus spiral). Dengan adanya siklus tersebut diharapkan semakin lama akan semakin dapat meningkatkan perubahan dan perolehan hasil belajar siswa. Siklus I dilaksanakan pada tanggal 2 November 2020. Siklus II dilaksanakan pada tanggal 9 November 2020. Sedangkan siklus III dilaksanakan pada tanggal 20 November 2020. Sumber data berasal dari guru, siswa dan dokumen. Data siswa diperoleh melalui pengamatan terhadap aktivitas siswa, hasil pretestt dan posttest siswa, hasil evaluasi tiap siklus. Data guru diperoleh melalui pengamatan terhadap perencanaan dan pelaksanaan dalam pembelajaran. Lembar pengamatan terhadap performansi guru menggunakan lembar observasi komponen guru. Lembar observasi komponen materi merupakan lembar penilaian terhadap isi materi. Data dokumen berupa daftar nama siswa, daftar nilai siswa, RPP, fotofoto maupun video pembelajaran, hasil pretest dan posttest.

\section{HASIL DAN PEMBAHASAN}

Sebelum melakukan siklus, peneliti melakukan proses pembelajaran dengan menggunakan metode ceramah dan tanya jawab, hasil studi menunjukkan bahwa: a) skor rata-rata (mean) hasil belajar siswa baru mencapai 56,3 (dari skor maksimal ideal 100). Sebaran skornya, ada 3 siswa (25\%) memperoleh hasil belajar kalimat saran pada kategori tinggi dan sudah mencapai KKM; 6 siswa (50\%) berada pada kategori sedang dan masih dibawah KKM; 3 siswa sisanya (25\%) mencapai skor pada kategori rendah dan jauh dibawah KKM. b) Pada kondisi awal tingkat keterampilan memberikan kalimat saran dalam masalah sederhana, dengan kriteria penampilan, bahasa, isi, mencapai $8 \%$ (dari skor ideal 12). Distribusinya adalah: ada 1 siswa dengan kategori skor tinggi artinya hanya $8 \%$ peserta didik mampu memberikan kalimat saran dalam masalah sederhana, dengan kriteria penampilan, bahasa, isi, 58\% (7 siswa) memiliki skor yang berada pada kategori sedang artinya hanya mampu menampilkan dua kriteria, dan 33\% (4 siswa) memiliki skor pada kategori rendah, artinya peserta didik belum mampu memberikan kalimat saran dalam masalah sederhana, dengan kriteria penampilan, bahasa, isi.

Siklus I dilaksanakan pada tanggal 2 November 2020. Siklus II dilaksanakan pada tanggal 9 November 2020. Sedangkan siklus III dilaksanakan pada tanggal 20 November 2020. Materi yang dikembangkan adalah materi Kalimat Saran. Pada siklus setiap guru menggunakan model guided discovery learning. Tahap pelaksanaan tindakan akan dilakukan sesuai dengan langkah-langkah pada model guided discovery learning yaitu: Introduction (Pendahuluan), Review (Pengulangan), Overview (Gambaran), Investigation (Penyelidikan), Representation (Representasi), Discussion (Diskusi), Invention (Penemuan), Application (Aplikasi), Summary (Kesimpulan), Assesment (Penilaian).

Setelah melakukan analisa dari tiap data yang diperoleh dari tiga siklus yang dilaksanakan, maka dapat disimpulkan bahwa penggunaan model pembelajaran guided discovery learning dapat peningkatan keterampilan memberikan kalimat saran dari masalah sederhana, dari kondisi awal, siklus I, siklus II dan siklus III.

Tabel 1. Komparasi Tingkat Keterampilan Memberikan Kalimat Saran

\begin{tabular}{lcc}
\hline \multirow{2}{*}{ Pembelajaran } & \multicolumn{2}{c}{ Peningkatan Keterampilan Memberikan Kalimat Saran } \\
\cline { 2 - 3 } & Mean & \% Kenaikan \\
\hline Kondisi Awal & 5,0 & - \\
\hline Siklus I & 6,7 & 34 \\
\hline Siklus II & 9,3 & 39 \\
\hline Siklus III & 10,3 & 11 \\
\hline
\end{tabular}


Dari data dalam tabel 13 diatas, diperoleh temuan: a) pada kondisi awal rata-rata tingkat keterampilan memberikan kalimat saran dari masalah sederhana peserta didik baru mencapai $34 \%$. b) pada siklus 1 rata-rata tingkat keterampilan memberikan kalimat saran dari masalah sederhana peserta didik mencapai 6,7. Capaian ini menunjukkan peningkatan sebesar 39\% c) pada siklus II, rata-rata tingkat keterampilan memberikan kalimat saran dari masalah sederhana peserta didik mencapai 9,3 yang menunjukkan peningkatan sebesar $39 \%$ dari siklus 1. d) pada siklus III, rata-rata tingkat keterampilan memberikan kalimat saran dari masalah sederhana peserta didik mencapai 10,3 yang menunjukkan peningkatan sebesar $11 \%$ dari siklus III. Peningkatan ini dapat divisualisasikan dalam grafik 1.

Grafik 1 Komparasi Keterampilan Memberikan Kalimat Saran dar Sederhana

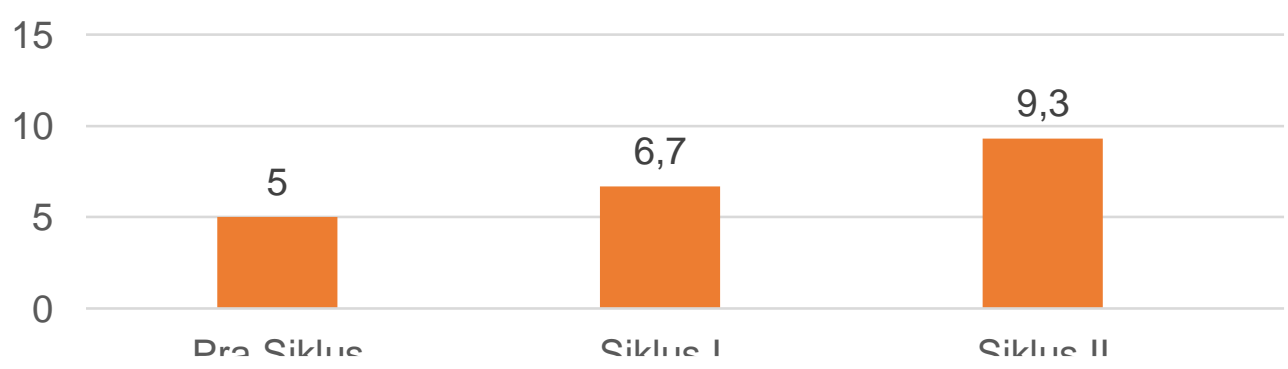

Peningkatan hasil belajar peserta didik dalam pembelajaran mupel Bahasa Indonesia materi kalimat saran melalui model guided discovery learning dapat dilihat dalam bentuk tabel 2:

Tabel 2 Komparasi Data Deskriptif Pretest dan Posttest

\begin{tabular}{lcccc}
\multirow{2}{*}{ Pembelajaran } & \multicolumn{2}{c}{ Pretest } & \multicolumn{2}{c}{ Posttest } \\
& Mean & \%Kenaikan & Mean & \%Kenaikan \\
\hline Kondisi Awal & 45 & - & 54 & - \\
\hline Siklus I & 50 & 11 & 58 & 7 \\
\hline Siklus II & 55 & 10 & 80 & 38 \\
\hline Siklus III & 76 & 38 & 85 & 6 \\
\hline
\end{tabular}

Berdasarkan data di atas terdapat peningkatan hasil belajar dan ketuntasan belajar dalam pretest dan posttest dari siklus I sampai siklus III. Pada tabel 14 menunjukkan nilai rata-rata kelas 76 pada pretestt dan 85 dalam posttest telah memenuhi KKM.

\section{SIMPULAN}

Berdasarkan hasil penelitian dan pembahasan yang telah disajikan dapat disimpulkan bahwa penerapan model guided discovery learning dapat meningkatkan hasil belajar mupel Bahasa Indonesia materi Kalimat Saran pada siswa kelas III SD Negeri 2 Metuk, Kecamatan Mojosongo. Adapun peningkatan ini ditunjukkan dengan temuan berikut: a) rata-rata rata-rata tingkat keterampilan memberikan kalimat saran dari masalah sederhana peserta didik mencapai 10,3 dari skor ideal 12. b) rata-rata hasil belajar peserta didik yang mencapai KKM meningkat menjadi 85.ini maksimal 200 kata. Menyajikan simpulan hasil kajian/penelitian, implikasi serta rekomendasi lebih lanjut yang menjadi prospek kajian/penelitian berikutnya. Implikasi pedagogis dari penelitian ini yaitu memberikan gambaran yang jelas tentang keberhasilan guided discovery learning dalam meningkatkan kualitas pembelajaran mupel Bahasa 
Indonesia materi Kalimat Saran pada siswa kelas III SD Negeri 2 Metuk, Kecamatan Mojosongo. Pada proses pembelajaran peranan guru yang paling dominan adalah sebagai fasilitator, karena guru memberikan fasilitas dan kemudahan untuk mencapai tujuan pembelajaran. Guru memberikan kebebasan pada siswa untuk dapat mengungkapkan gagasan maupun pendapatnya. Guru juga membimbing siswa yang mengalami kesulitan dalam melaksanakan kegiatan pembelajaran serta memberikan motivasi agar mendorong siswa supaya lebih aktif.

\section{DAFTAR PUSTAKA}

Agung, A. A Gede. (2005). Metodelogi Penelitian Pendidikan. Singaraja: Universitas Pendidikan Ganesha Singaraja.

Ani Widayati. (2008). Penelitian Tindakan Kelas. Jurnal Pendidikan Akuntansi. Indonesia. Vol. VI. No. 1. Tahun 2008.

Arikunto, Suharsimi dan Safudin. (2004). Evaluasi Program Pendidikan: Pedoman teoritis Praktis Bagi Praktisi Pendidikan. Jakarta: Bumiaksara.

Carin, Arthur A. (1993). Teaching Modern Science. Columbus: Macmillan Publishing. Edisi ke-tujuh.

Eggen, Paul \& Kauchak, Don. (2012). Strategi dan Model Pembelajaran. Jakarta: PT Indeks.

Fajar Rizki. (2020). Pembelajaran Jarak Jauh di Tengah Pandemi Covid-19, diakses darihttps://www.kompasiana.com/komentar/rizkifajar/5f34922cd541df5db576052 2/pembelajaran-jarak-jauh-di-tengah-pandemi-virus-covid-19, pada tanggal 19 November 2020 pukul 15.45.

Fathiyah Isbaniah. (2020). Pedoman Pencegahan Pengendalian Coronavirus Disease (COVID-19). Jakarta: Kementrian Kesehatan RI.

Sudjana, Nana. (2005). Penilaian Hasil Proses Belajar Mengajar Mengajar. Bandung: PT. Remaja Rosdakarya.

Suprijono, Agus. (2009). Cooperative Learning Teori dan Aplikasi Paikem. Yogyakarta: Pustaka Pelajar. 